\title{
16
}

\section{Character Strengths Interventions in Education Systems}

\author{
Jillian Coppley and Ryan M. Niemiec
}

Our current education systems, as with every other system, are designed to achieve the results they produce. In some instances, those results are cause for celebration, while others give rise to collective despair. Around the world there is a growing realization that many of our existing systems of education-at the classroom, school, state, and national level-are not constructed to produce results relevant to our modern world. The industrial age, one-size-fits-all, assembly line approach with a narrow focus on academics and memorization is mismatched to the needs of the dynamic and demanding information age in which we now live. Examples of this disconnect abound and reflect differences between the former era's demand for uniformity, predictability and independence and the current era's demand for diversity, flexibility, and interdependence (Erickson, 2012).

To explore the gap between current needs and current options, the leading education grantmakers in the United States gathered for a design thinking retreat (Grantmakers for Education, 2010). Through design charettes and immersive learning, they collaborated to articulate the requirements of the modern education system from the learner's perspective. They articulated a vision for learners as follows.

J. Coppley $(\varangle)$

Mayerson Academy, Cincinnati, OH, USA

e-mail: darwish.jillian@mayersonacademy.org

R. M. Niemiec

VIA Institute on Character, Cincinnati, OH, USA 
As a learner I need:

1. To feel that I am uniquely valuable in and for the world.

2. To know my value can be realized.

3. To have a map that shows me what is possible in my life and my experience as a learner.

4. To have help navigating that map.

5. To enjoy learning experiences to reflect who I am.

6. To access financial, technical, and socio-emotional resources to follow me on my journey.

Clearly, these leaders are describing an education experience quite different from the dominant, monolithic focus on academic learning in current systems around the world.

To bridge the chasm between the industrial and knowledge age models of education, leaders have energetically implemented "reforms" focused on school finance, standards, assessment, accountability, class size, teacher preparation professional development, and school choice. However, after years of determined effort and billions of dollars (Connel, Martin, \& Moore, 2002), very little has changed (Payne, 2008). One reason experts cite for these disappointing results is the fractured, add-on nature of the efforts and a lack of a systems approach to change (Betts, 1992).

As positive education - and within it, the subset of strengths-based interventions-gains momentum and scales to larger audiences, sustained implementation and impact will be supported by a systems approach to change. A systems approach will mitigate the potential for positive education to become yet another disappointing footnote in the story of education reform.

The majority of this chapter will focus on the inductive, practice-based codification of promising practices for a systems approach to strengths-based interventions. Before addressing this topic, a modest history and beginning practice-based categorization of the emerging array of character strengths interventions are presented.

\section{Why Character Strengths? the Meeting of Science and Practice}

It is important to note that the concept of character strengths can frequently be combined with a generic use of the word "strengths" that includes a wide variety of heterogeneous approaches (McQuaid \& Lawn, 2014). The examples in this discussion are focused on the use of Values in Action (VIA) 
Character Strengths and Virtues, which is one of the most highly regarded and widely used tools in the field of positive psychology.

As positive psychology was articulated by Martin Seligman in the late 1990s, the focal point of positive traits, or positive character, was named as one of three central themes for the field (Seligman, 1999). Originally focused on positive youth development, this new focus on positive character evolved into an expansive three-year project involving 55 leading scientists. The group intended to address questions including: What is best about human beings? What have the philosophers, theologians, and other leading thinkers across time and cultures said about what constitutes a good and fulfilling life? How can we understand individual differences? The result of their work was a groundbreaking classification of twenty-four human strengths nesting under six overarching virtues. This is referred to as the VIA Classification of Character Strengths and Virtues (Peterson \& Seligman, 2004). With the new classification, a common language of character strengths was defined for the first time. In addition, measures of character strengths were created and validated for adults and youth, referred to as the VIA Inventory of Strengths (colloquially, the VIA Survey) and the VIA Inventory of Strengths for Youth (colloquially, the VIA Youth Survey). The VIA Survey is taken by someone somewhere in the world every fifteen seconds, a frequency which has been steadily increasing each year. Eight million people representing every country across the globe have now taken the VIA Survey (Niemiec, 2018).

The research on VIA Character Strengths and Virtues marks a clear departure from prior character efforts in that the previous science on character was scant and widely critiqued for poor research support and inconsistent approaches (Berkowitz \& Bier, 2007; McGrath, 2018; Peterson \& Seligman, 2004). But following the VIA Classification, well-over six hundred studies have been published outlining a variety of positive outcomes, directions for character strengths, applications in different domains and disciplines, and new interventions. Over 50 specific studies relating to schools, children, and adolescents have been published. These studies provide new insights and lay the groundwork for future science. To review short summaries of all these studies, categorized by topics, with full citations, see VIA Institute (2019). A modest selection of studies includes:

- There are a number of positive outcomes connected with particular character strengths in youth. In a study of 196 children taking the VIA Youth Survey, zest, love of learning, perseverance, and social intelligence showed the strongest positive relations to school-related positive affect, 
while teamwork, hope, self-regulation, and love showed the strongest negative correlations with negative affect at school (Weber, Wagner, \& Ruch, 2016). Character strengths also showed an important relationship to school achievement. Meanwhile, among high school students, other-oriented character strengths (e.g., kindness, teamwork) predicted fewer depression symptoms while transcendence strengths (e.g., spirituality) predicted greater life satisfaction (Gillham et al., 2011).

- In studies looking at school transitioning, parents' intellectual, interpersonal, and temperance strengths related to their child's adjustment to first grade (Shoshani \& Ilanit Aviv, 2012). In a longitudinal study of adolescents' transition to middle school, intellectual and temperance strengths predicted school performance and achievement, interpersonal strengths related to school social functioning, and temperance and transcendence strengths predicted wellbeing (Shoshani \& Slone, 2013).

- Leading educators are now drawing links between the 24 character strengths and twenty-first century competencies-cognitive, interpersonal, and intrapersonal competencies-identified by the American National Research Council. These interconnections not only offer new mechanisms for developing character strengths, but they also offer new avenues for schools to reach their success goals (Lavy, 2019).

- Multiple studies have found positive outcomes for programs designed to develop character strengths. Eighth-grade students participating in an intervention program involving five, one-hour character strengths classroom activities had significant benefits to wellbeing compared to those in a comparison group (Oppenheimer, Fialkov, Ecker, \& Portnoy, 2014). Another study examined a six-session, character strengths program for nine to twelve-year-old students in a classroom setting compared with non-randomized controls. After three months, the strengths group scored significantly higher on class cohesion, relatedness, and need satisfaction. The students in the strengths group also scored lower on class friction and higher on positive emotion, classroom engagement, and strengths use (Quinlan, Swain, Cameron, \& Vella-Brodrick, 2014). Changes in teacher strengths-spotting (the identification and subsequent explanation of character strengths identified in others) explained the outcomes of classroom engagement, positive affect, and needs satisfaction (Quinlan, VellaBrodrick, Gray, \& Swain, 2019). In a study of 319 adolescent students between the ages of twelve to fourteen, students were divided into two groups in which two-thirds of the students received character strengthsbuilder activities and strengths challenges within the school curriculum (called Strengths Gym), and one-third did not. Students who participated 
in strengths interventions experienced increased life satisfaction compared to the controls (Proctor et al., 2011).

- Character strengths are frequently reported by educators and students as the most memorable and impactful program element within schools implementing positive education programs. While this is anecdotal evidence from several programs across the globe that we have spoken with, some research on positive psychology programming has published similar observations from participants (Huffman et al., 2016).

\section{Defining Character Strengths Programs}

The above insights on the needs of learners expressed by philanthropic leaders in education reflect growing advocacy for education systems that consider more than the academic development of learners and create a new normal where social and emotional development is integrated across students' academic learning experiences (Calkins, 2015). Similar calls have come from the World Health Organization, United Nations Convention on the Rights of the Child (Lavy, 2019), The World Government Summit (Helliwell, 2019), The World Economic Forum (World Economic Forum, 2016), and The Organization for Economic Co-operation and Development (OECD, n.d.).

The interest of leaders around the world has fuelled the growth of character education interventions, which constitute a subset of positive education interventions (Berkowitz, Bier, \& McCauley, 2016). However, according to research by McGrath (2018), there is substantial variability in programs identified as character education. Figure 16.1 summarizes different approached to strengths-based interventions. Two sets of critical distinctions for defining and categorizing programs are offered below.

\section{Prescriptive Versus Descriptive}

The two broadly scoped and alternative aims of character strengths interventions can be considered through the meaning of the two contributing Latin roots of the English word education: educare, which means to train or to mould, and educere, which means to draw out (Craft, 1984). Of note, this etymological root, combining opposing ideas in one word, reflects the needs of the former industrial model of education of inculcating knowledge within the next generation in the mould of the past, and of the information age model, with its demands to develop the current generation to critically analyse and create solutions for challenges we have yet to even imagine. They 


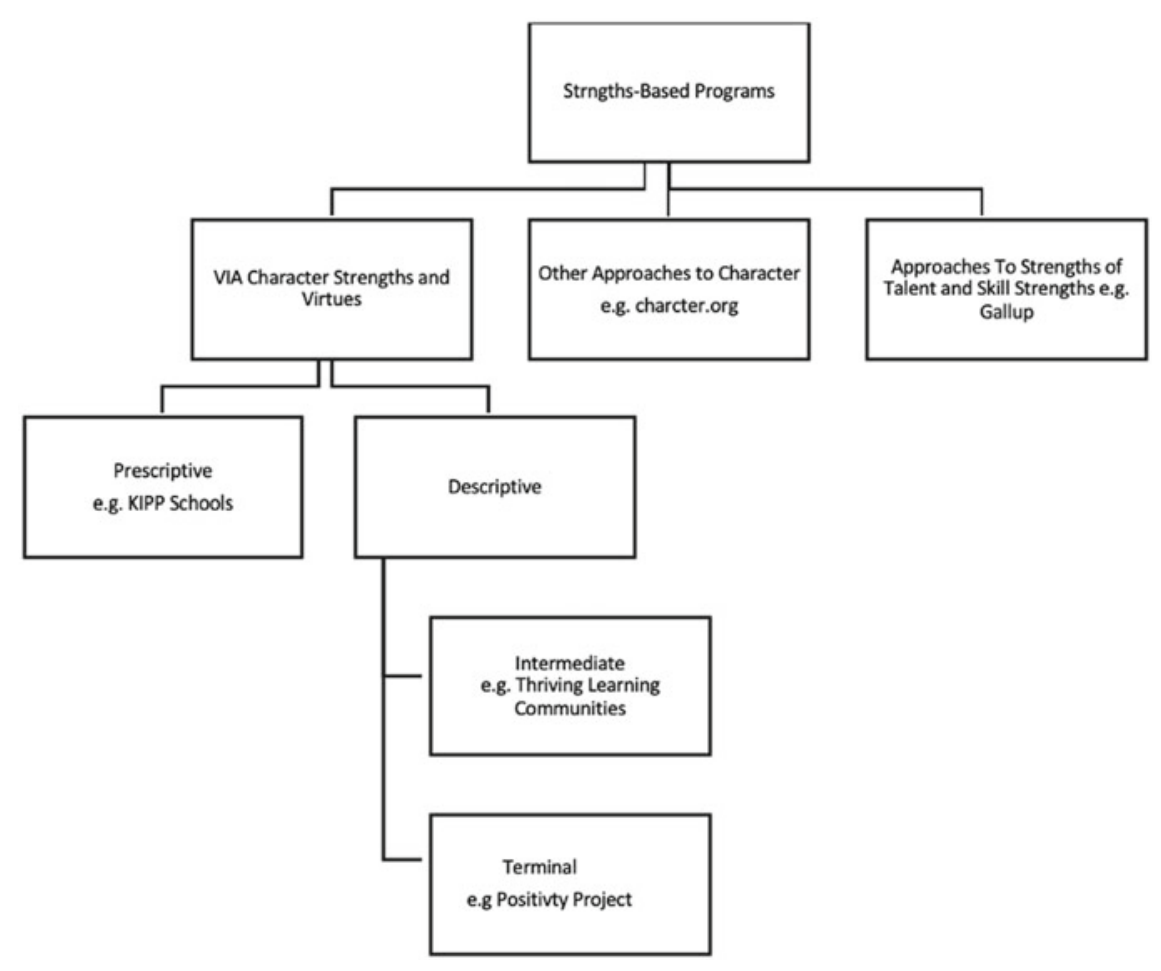

Fig. 16.1 Categorizing strengths-based interventions

are also respectively related to the prescriptive and descriptive categories of program interventions.

The prescriptive category of character strengths interventions is aligned to the educare meaning of education, as these interventions privilege certain character strengths and focus on uniformly instilling them within all learners. Neal Mayerson, chairman of the VIA Institute on Character, suggests that prescriptive character education is analogous to the process of moulding clay (Linkins, Niemiec, Gilham, \& Mayerson, 2015). The potter (school, educator, or other authority) works to transform the clay (student's character) into a predetermined form. Character Counts!, a well-established program in the United States, is said to help enforce core values and instil the Six Pillars of Character and is a prototype of a prescriptive approach (Josephson Institute, 2013) Another prescriptive example can be found with the 240 KIPP Charter schools which limit their approach to seven character strengths (KIPP Foundation, n.d.). Such approaches are widespread in character programs in education systems (see www.goodcharacter.com). However, one of the challenges to this approach is identifying which traits should be endorsed. This 
determination is frequently highly controversial with suggestions of racial, gender, community, and cultural biases.

Descriptive character strengths interventions are more closely aligned with the educere notion of education, seeking to draw out the learners' personal narrative around their unique strengths of character. In contrast to the metaphor of prescriptive approaches in which an authority figure/institution is moulding clay, descriptive approaches are analogous to watering seeds. Every student is viewed as a unique seed that will grow and thrive if he or she is provided with the proper conditions in his or her environment and if they are approached with respect to their individual uniqueness. In other words, the approach of the educator is one of discovery and exploration (asking questions about the student, providing opportunities for new discovery), experimenting with strengths, and building the student's unique strengths to help the seed grow into what it was meant to be (Linkins et al., 2015). Descriptive approaches typify the emerging science of wise interventions, as defined by Gregory Walton, Carol Dweck, and other scholars at Stanford University (see Walton, 2014). Wise interventions involve the deployment of a simple lever (i.e., the intervention) that is appropriately timed for the individual, highly contextual, and responding to a psychological need within the student. Examples inside and outside the school context are mounting (e.g., Finkel, Slotter, Luchies, Walton, \& Gross, 2013; Yeager et al., 2014).

Descriptive approaches, anchored in the robust research of the 24 VIA character strengths, are designed to speak to both our individual and our shared humanity. VIA provides a language that acknowledges the presence of all 24 character strengths within each of us and an understanding that all of the character strengths contribute to positive outcomes and should be valued. Simultaneously, programs based on the VIA character strengths seek to activate each individual's unique strengths' profile.

\section{Terminal Versus Intermediate}

Within the descriptive approach there is another distinction that defines character strengths interventions. This nested categorization is determined by the degree of centrality that character strengths play in the intervention. In the terminal approach, the singular focus of the effort resides in developing the knowledge and use of character strengths. Programs such as Strengths Gym (http://www.pprc.gg/products/), described as "a course for children designed to enable students, teachers, and others to learn about, recognize, build upon, and use their character strengths more" (para. 1), is one of the most well-known recent examples. 
With the intermediate approach, character strengths are seen as a powerful, appreciative lever to develop other capacities such as the PERMA (positive emotions, engagement, relationships, meaning, and accomplishment) elements of wellbeing (Seligman, 2011) or social and emotional learning competencies (Au \& Kennedy, 2018). These approaches activate narrative identity through character strengths in a manner that fuels the development of particular skills (see McGrath, 2018, for more on this distinction). According to Lynn Ochs, Senior Director of Education Programs at Mayerson Academy, Thriving Learning Communities ${ }^{\mathrm{TM}}$ (TLC), a robust K-12 character strengths program

uses a strengths-based lens to ground understanding of self-awareness, selfmanagement, social awareness, relationship building, and responsible decision making. The scope and sequence of the curriculum defines the strengths associated with each of the five elements of social and emotional learning in a flexible, easy to follow structure and set of learning experiences. With these skills, students expand engagement, performance and learning that will support their progress well into the future. (L. Ochs, personal communication, August 1, 2019)

Research has found that teaching character strengths with social emotional learning (SEL) competencies is particularly effective in producing positive outcomes with students (Berkowitz, Bier, \& McCauley, 2016).

\section{Implementing Character Strengths Interventions}

To date, program evaluation of descriptive classroom interventions using the lens of character strengths to develop social and emotional learning competencies has evidenced positive outcomes related to engagement, learning, attendance, and behaviour (Mayerson Academy, 2018). These encouraging findings result from the smart application of the robust science of character strengths, but practice-based evidence suggests that the success and sustainability of the implementations is equally indebted to the recognition that the intervention requires a systems approach to change. The case of designing character strengths interventions through a systems approach represents a unique and powerful opportunity. As the discussion and practice-based examples below will detail, character strengths are simultaneously the content of intervention and an effective process element for systems change. 
The remainder of this chapter is devoted to describing elements of a systems approach to implementation that is emerging from exemplary character strengths interventions around the world. While the concepts have arisen inductively from work with more than one hundred schools, in-depth interviews were conducted with fourteen leaders to detail the stories of practice below. Participating institutions vary in their populations, age groups, locations, and structures. They include $\mathrm{K}-12$, higher education, informal education, and religious education. The economic diversity is considerable with one school having $100 \%$ of its population qualify for free and reduced lunch and another with an affluent tuition-paying population. They are located across the United States and in Hong Kong.

To presage the discussion below, critical components of a systems approach that have emerged from this work and are being refined by an ongoing dialectic between research and practice are listed below:

1. Inviting participation: Privileging personal choice and engagement where possible in place of mandates and edicts for compulsory participation.

2. Answering why first: Getting the order of operations right by postponing the question of "how" to follow the question of "why".

3. Building capacity from the inside: Inspiring internal leadership and change that begins with shifting individual mental models first.

4. Creating connections, practically and personally: Embedding, not bolting on, the intervention in the current system to increase prospects for sustainability and strengthen human connection.

5. Learning continuously: Sustaining the effort with reflection, a learning community, and feedback loops.

\section{Inviting Participation}

Real change does not happen solely with mandates and edicts from the top unless those directives are continually supported by extraordinary effort and resources. No Child Left Behind (the name for the reauthorization of the primary U.S. federal law for K-12 general education) unmistakably created change, but it is beyond credulity to believe that U.S. schools could have been permeated so significantly by the high-stakes testing agenda had there not been extraordinary and persistent resources to ensure compliance. Indeed, once external effort and resources disappeared, so did many of the changes (Understood.org, n.d.). 
Authentic and sustained change begins with an invitation to participate in the proposed intervention and a commitment to collective engagement. In the name of efficiency, this essential aspect of initiating a new effort is frequently missed. Instead of saving time, the missed opportunity to engage system stakeholders takes more time in the long run. In the words of systems thinking expert Margaret Wheatley:

I've often learned the hard way that participation is not an option. As organizational change facilitators and leaders, we have no choice but to figure out how to invite in everybody who is going to be affected by this change. Those that we fail to invite into the creation process will surely and always show up as resistors and saboteurs. (Wheatley, 2001, para 15)

This is an excellent example of a frequently cited systems axiom, go slow to go fast.

Being invitational is particularly important in the context of strengthsbased interventions, as each individual is unique in the character strengths they can contribute and bring forth to their own life, the classroom, and the school as a whole. Therefore, each student is a valuable contributor. When individuals are encouraged to utilize their unique strengths (often called signature strengths), research tells us that wellbeing improves (Gander, Proyer, Ruch, \& Wyss 2013; Schutte \& Malouff, 2018), passion and interest build (Forest et al., 2012), and thriving is enhanced (Bu \& Duan, 2018).

Inviting participation in practice. Discovery College is an independent school in Hong Kong that brings together 45 nationalities in its learning community. The school is committed to the development of "independent, critical and creative thinkers, equipped with the skills, attitudes and values to contribute positively in this complex world in which we live" (http://www. discovery.edu.hk/about-us/). Educators at Discovery College have committed to creating a unique approach to enabling students to flourish and have integrated character strengths as an essential element of their strategy. The school's unique invitational approach to engagement is what they have come to call bubbling and brewing. In a recent phone call with Chris Barr (Head of Primary), Leanne Sercombe (Teacher Librarian), Nerida Kiprotich (Year 1 Teacher) and Tracey Chitty (Student Counsellor), the group described the beginning of their efforts. Barr commented: "We knew this couldn't be mandated and instead people would have to be given space and time to explore and experiment". The early conversations were a dynamic and organic process of diverging and converging. While an early professional learning opportunity was provided for all colleagues, the follow-up workshop experience allowed educators to select where to $o p t$-in. From there, informal leaders 
emerged to go deeper with additional rigorous reading and study into their self-identified areas of interest. According to Barr, it was critical to: "go with the flow. Go where people had the most energy". Ultimately, the guiding team would be comprised of colleagues in formal leadership roles but would also include those whose personal interest was sparked and who subsequently accepted the invitation to engage.

The character strengths implementation at Northern Kentucky University, a growing metropolitan university of more than 14,000 students, shares the same spirit. After a false start with a strengths-based intervention in which participation in a professional learning experience was mandated, a lead team of learners invited colleagues who were curious about the work to attend workshops. If the workshop piqued their interest further, participants were invited to attend advanced training to become training facilitators. According to Carly Rospert, Director for Innovation and Impact at Mayerson Academy, this effort led to hundreds of faculty and staff being trained in the science and application of character strengths across nearly every department in the University inside the first year.

Whitfield School is an independent school in St. Louis, Missouri devoted to cultivating "ethical, confident, and successful students" in a "close-knit academic environment where each student's strengths are known and cultivated". John Delautre (Head of School) and Ginny Fendell (Director of Health and Wellness) extend an invitational approach to faculty, staff, and families in their school community. Fendell shared:

with new faculty or new parents, we don't impose, instead we take a conversational approach. Using the shared language of the character strengths, we discuss the new families' unique strengths as a unit and how they might contribute to our community. It isn't onboarding, it is inboarding, inviting them into the community to share what they have to offer.

Interviewed educators consistently asserted that successful beginnings included invitations that were backed by strong leadership support and a compelling research foundation underpinning the work.

\section{Answering Why First}

Change efforts frequently get important questions out of order by attempting to answer how we do this before answering why we are doing this (Block, 2003). When how comes before why, we miss the opportunity to welcome individuals as participants and ignite their engagement, ownership, and 
passion. When an organization's members explore the specific connection between a proposed intervention and their shared organizational vision, mission. and values, they build a unity of purpose. Purpose is what defines a system and transforms colleagues from co-inhabitants to co-creators, thereby strengthening relationships, critical in the process of creating change. Shared purpose also brings coherence to the independent actions and efforts of individuals, making it possible to meet even the most challenging organizational goals. When colleagues deepen this exploration by connecting the intervention with a personal sense of purpose and unique character strengths, a sense of personal ownership develops (Kim, 2008). This is yet another way in which character strengths can play a role as both the intervention content and the process of the intervention.

Answering why first in practice. Answering the question of why can come from an unmet challenge or an aspiration to stretch to a new possibility. At J. P. Parker School in Madisonville, Ohio, an elementary school serving 300 pre-school to sixth-grade students, Kimberly Mack (Principal) and Pamela Knox (School Community Coordinator) talk about a void they sought to fill. Dr. Mack reflected: "The advisory and character strengths are very personal to me. I knew we had a void with our students. We weren't always seeing their empathy, patience and compassion and I saw how implementing this work could help fill that void". Knox elaborated by saying:

It's not that they didn't have these things before but with this work we are giving them voice to bring their strengths to the table. The character strengths empowered learners to bring out the empathy, patience and compassion they already had. We had a gift from Dr. Mack. She could see why this was important and she helped us to see and understand why it was important and she reinforced it. If we are strong, acting with intention and with purpose, we can give that to children.

In an earlier case study, Knox said: "ultimately, the adults are working together toward a common goal of empowering learners to realize their full potential. We've given them permission to sit in their own greatness" (Mayerson Academy, n.d.).

At Congregation B'nai Jeshurun, a vibrant and welcoming Reform Congregation in Short Hills, New Jersey, Senior Rabbi Matthew Gewirtz is passionate about uncovering the tools and practices that lead to meaningful Jewish identity exploration. Tess Levine (Religious School Director) shares this passion, and together they are challenging the status quo of religious education to make it deeper and more relevant to young learners. After reading a number of books and research articles, Gewirtz and Levine invited 
other senior leaders in the Congregation into the conversation and began to build a shared sense of purpose through robust dialogue. Gewirtz led the group to expand the boundaries for their work by considering the temple as a Center for Human Flourishing. He prioritized the engagement of board members and congregation leaders with language that was meaningful to them in order to build a shared sense of purpose around the concept of flourishing. Levine shared that having this strong sense of purpose was essential in fuelling the perseverance change requires saying: "When it is so powerful and meaningful, you know that no matter the obstacle or barrier, this is our goal".

The Wellston City School District located in Southeast Ohio has a stated philosophy to serve the whole child. However, Superintendent Karen Boch shared: "When you looked at our strategic plan you would not have known it. The plan was overwhelmingly focused on academics". Brandi Cupp (Principal) and Beth Duffy (Director of Curriculum and Instruction) agreed, indicating that conversations were surfacing among educators across the district about expanding thinking and planning in a way that reflected the district's intentions. They knew this expanded perspective could address diverse challenges from student behaviour to teacher and leadership retention. The possibilities to close the gap between the aspiration and the plan became the rallying call and provided a shared purpose for the work.

Fendell shared another perspective in answering the why question. She shared her experience (consistently supported by survey research) that an individual's choice to become an educator is routinely fuelled by a desire to help others grow. While the demands of the work and the recent challenges and constraints can dull that vision, Fendell shared a story that brought this longing and a shared sense of why into full focus again. A senior teacher in the school recounted that at the first parents' night of the year, he asks parents what they want for their children that year. He indicated that no one ever says I want my child to have these tests or these advanced placement classes. Instead they say "I want them to know who they are", "I want them to understand and use their strengths", "I want them to be happy and passionate". According to Fendell: "In this way they have a shared purpose with parents because that is exactly what this work is about and that is what we must communicate".

\section{Building Capacity from the Inside}

At its core, a systems approach to creating successful strengths-based interventions begins with building a shared knowledge base and language for knowing, seeing, and applying strengths as individuals. Research has 
repeatedly documented the essential elements of effective capacity-building professional development (Sprinthall, 1996). There is a persistent call in the research for professional learning to be context aware, with research further suggesting that social-psychological interventions are particularly context-dependent. Scaling efforts from the nested systems of classrooms to schools, to districts, and beyond requires more than distributing content, with context-sensitivity playing a large role in determining effectiveness (Yeager \& Walton, 2011). For successful and sustained efforts to create a shared knowledge base, language, and practices, a nuanced understanding of environment and culture is required and therefore the effort is best led from the inside, by school-based leaders.

In the work of character strengths interventions there is an interesting double meaning to lead from the inside. The work is optimally led from within the organization to ensure context sensitivity, but it also begins with the educator's personal experience. The individual's personal system of thought can be seen as a fractal within the increasingly larger fractals of the classroom, school, district, and beyond. Shifting individual mental models and letting go of existing beliefs to create space for knowing, seeing, and applying personal strengths creates the commitment and sense of authenticity that the successful implementation requires. Capacity-building is not just a matter of direct instruction, but rather requires exploring the concepts in the context of one's own life. Initial in-depth personal exploration is another example of the systems axiom going slow to go fast, as it takes time for the required exploration but encourages the in-depth processing that research suggests makes it possible to transfer and apply understanding to new settings (Chase, Chin, Oppezzo, \& Schwartz, 2009). In this way, the professional learning experience is a mirror of the pedagogical expectation for classroom and school implementation, which includes both explicit instruction and wholistic integration that becomes the default way of acting in the classroom and school. Mathew White and Lea Waters (2015a) report that when teachers operate in this manner with a strengths-based perspective, they create rapport and bonding with students and build a culture which is highly transformational.

Building capacity from the inside in practice. Returning to Congregation B'nai Jeshurun, educators acknowledged that external experts can give the work authority and credibility as they share research, expertise, and organizing capacity, while maintaining freedom from possible internal political challenges. However, they indicated that program implementation success was ultimately related to the degree to which there was committed internal leadership and sponsorship. In fact, Rabbi Matthew Gewirtz went so far as to say: "We could have ruined it if we brought an expert in house. We would 
have felt like we didn't have to do the work. On our own, we had to live the work ourselves". His colleague, Tess Levine, continued by noting that having the originating leadership team continue to guide the work

forced everyone in the system to get involved and to drive change in their own way. We would have lost some of the creative energy if that hadn't been true. When there are fifteen of us asking how we are going to make something happen, you feel connected to one another and to the work.

Educators also clearly shared the perspective that the work begins within each individual as s/he begin to shift her/his personal mental model. At J. P. Parker School, Community Coordinator Pamerla Knox described the first workshop as: "an awakening of self-understanding", allowing her to understand, "why I see things the way I do". Because of this new understanding, Knox asserted that educators "share themselves in new ways and act differently - in a way that transforms culture. Character strengths are reshaping the way we all behave and interact". As this happens, educators "can say this is how this work can be implemented here - how it would work here. I would do this in my classroom, and this is how you could also implement". Deeply held personal knowledge and shifting mental models have opened up new learning experiences for the entire learning community at J. P. Parker. As an example, a third-grade teacher created a panel of teachers and parents who deeply understood their own character strengths and to whom children could ask questions about how they use their character strengths and what their strengths mean to them.

\section{Creating Connections, Practically and Personally}

Another central axiom of systems thinking is that everything is connected, and careful attention must be paid not to optimize a part of the system at the expense of the whole system (Ackoff, 1986). In practical experience this means that if there is an attempt to simply bolt an intervention onto part of the system, it will be rejected (Schweiger, Stouten, \& Bleijenbergh, 2018). To be sustained, new elements must be rooted in the system's existing structures and processes as an expression of internal consistency and coherence grounded in purpose. Embedding the intervention holistically in an organization promotes effective implementation and sustainability, as research suggests that organizational structure defines individual performance (Senge, 1990). Embedded process and structure can provide guardrails to support high program fidelity. Opportunities for integration appear in nearly every 
aspect of classroom processes, including curricular instruction, community building, communication, assessment, and family and community connections, with similar opportunities at the school level.

Creating connections, practically and personally in practice. There is good news and bad news in implementing character strengths interventions. As Tracey Chitty, student counsellor at Discovery College, says: "It is easy to pick up, and easy to put down". Building shared language and anchoring the character strengths implementation to existing practices were cited as essential to sustain the work and to make it more difficult to put down. Creating practical connections had a highly prized secondary impact on developing personal connections.

At Congregation B'nai Jeshurun, the work with teachers was treated as a reframing of work they were already doing so as not to feel like an add-on. Congregation B'nai Jeshurun connects character strengths to nearly everything they do, including board meetings, staff meetings, the physical environment, holidays, and celebrations. Rabbi Gewirtz made the analogy that connecting the work to existing practices is like planting a garden of beautiful perennials that continue to grow without significant tending, and almost magically, continue to thrive year after year. There is also a secondorder effect with young learners. According to Tess Levine, their learning does not just stay in religious school: "Students have a language with which they can take their Jewish values into the world - in their school, sports teams, families, and communities".

Additional examples of connecting character strengths interventions to existing practices range from athletics, equity and inclusion efforts, dress code, comment writing for students, and advisory meetings to honour council at Whitfield School. At Northern Kentucky University, character strengths have been systemically embedded in the services of the campus Wellness Center and into the University's matrixed approach to human resources, which is helping the department shift from compliance-driven approach to one of advising and consulting.

Wellston educators identified parent open houses, student journals, daily announcements, newsletters, and persistent visual displays of the character strengths language in classrooms and hallways as points of connecting and embedding. According to Principal Brandyl Cupp, the intersection of character strengths with Positive Behaviour Interventions and Supports (PBIS) at Wellston has been particularly powerful. Connecting the character strengths work to PBIS has given the school a "common philosophy of discipline". Brandyl further noted: 
PBIS provides an instructional approach to discipline, activating character strengths helps learners make good decisions. PBIS is the what and the language of character strengths is the how. The character strengths work is about recognizing what is valuable in kids - that is the key right there - let them know they are important, even inside discipline. This sets the stage for relationships which are the foundation for everything. Creating a human connection between students and staff is one of the most important things this work has done for us. It creates a bridge when there is a disconnect and it is a game changer. If you have a relationship it helps to build capacities for children. When the relationship is there anything is possible. If not, very little is possible.

Other educators gave similar primacy to establishing a shared language and the impact of connecting character strengths to existing school practices, noting these practical connections supported strong personal connections. At Whitfield School, Head of School John Delautre shared that: "the common language of character strengths connected us, got us out of our silos and created new relationships and potential". The educators at Wellston agreed, noting:

the climate is changing. The way our staff interacts with one another has changed. Building Council used to be very popular. It is the place that district leaders hear all the problems occurring in the buildings. Now, we have very few people who attend and we hear the problems have been solved at the school level. In the same way it is empowering to our students, it is empowering to our staff. This is because relationships are being reconstructed in a fundamental way". Similarly, the team at Congregation B'nai Jeshurun indicated that "there is a deeper level of understanding for one another. We are more open and honest about who they are and what our strengths are so that lends itself to interpersonal relationships being more honest and more truthful. The strengths on your desk don't feel intimate but the conversations they lead to are. You talk about how you developed them, why they are important. And as the adults do that, it also happens with students and between students.

J. P. Parker has experienced similar impact on relationships with families in the school. Principal Kimberly Mack noted:

Parents know the language. They are more tolerant with staff at school and the teacher-parent relationship is stronger. It is not as defensive. It is more respectful and more trusting. Parents seem to know now that I am here to bring the best out in your kid, and maybe even you. Actually, there is a new level of courtesy and kindness throughout the building. 
Educators from Discovery College have had similar experiences, with Teacher Librarian Leanne Sercombe indicating that:

the language from staff, students, and parents has transformed. It is truly now naturally embedded in casual conversations. It's not only language that is used when things are going well. It's heard when redirecting individuals or trying to build understanding.

At J. P. Parker, character strengths are integrated across the school's practices as with the examples above, but they are also embedded in the school's curricular approach to the school's theme of global environmental literacy. Not only does this integration happen during the school day, but also in after-school programs with the Parent Teacher Organization (PTO) and community partners. Dr. Mack reported that:

embedding character strengths into every aspect that you can is important. Our school, PTO, partners, community...we are all speaking the same language. Students hear it at home, at the rec centre, at the library. We are all a chorus singing the same song perfectly in tune.

\section{Learning Continuously}

Effective character strengths interventions require explicit instruction in the application of character science for both educators and students. This initial introduction must be informed by "the same level of research and planning that currently goes towards developing curricula for traditional academic subjects" (White \& Waters, 2015b, p. 113). But initial in-depth, highquality learning experiences, such as that provided by Mayerson Academy's Thriving Learning Communities Champions Institute (https://www.mayers onacademy.org/thrivinglearningcommunities/) are simply the beginning of an ongoing learning journey. Human social systems are dynamic and adapt over time. Engaging in continuous learning is a means to support effective adaptation and is necessarily a requirement within a systems approach to change. Karen Bohlin, head of the Montrose School in Medfield says: "to make virtue one's own, to develop strength in new and challenging contexts, requires personal effort every day" (Bohlin, n.d.). Reflective practice, learning communities, and feedback loops encourage and support required continuous individual and group effort.

While research provides a myriad of descriptions for reflection (Calderhead, 1989), Schoen's (1984) identification of reflective practice as a powerful learning tool and the practice by which professionals become aware of their 
implicit knowledge base and learn from their experience is most relevant to this conversation. In other research, reflection has been identified as the means by which educators can find the energy of vitality and self-renewal (Fullan, 1995), which is critically important in the cauldron of change. Yet again, there exists duality with this imperative as the reflection required to build a strengths-based life is a reflection of the larger imperative for system implementation.

The final component of continuous learning is a professional learning community. The potential and importance of professional learning communities for professional development have long been established (Stoll, Bolam, McMahon, Wallace, \& Thomas, 2006). In the case of strengths-based systems change, they not only provide a conduit to develop and exchange best practices, they also provide the opportunity to strengthen relationships as the learning community becomes the laboratory within which strengths-based applications can be tested. As this happens, relationships grow stronger and the community becomes a source of critical encouragement amidst the demands of change (Rospert, 2017).

Strong relationships support robust feedback loops, such as the Deming cycle of Plan, Do, Check, and Act, which is a momentous force for continuous learning (Moen, n.d.). The addition of using strengths in the feedback loop for testing strengths-based implementations can be particularly powerful (CIPD, 2017). Yet again, this is a learning experience for educators themselves that reflects expectations for classroom learning (Darwish, n.d.).

Learning continuously in practice. Beyond workshops, book studies, persistent prompts such as calendars, newsletters, and embedded meeting conventions, schools are making time for reflection, sharing best practices, and monitoring their work. At Discovery College, teacher Nerida Kiprotich reports that the team leading this work is comprised of a member from each year group. As they review the implementation of the work, and identify new developments and resources in the field, they take those ideas back to their grade level meetings. In this way the work is "kept alive in our team meetings with a constant drip of usable bits of information". The ideas get implemented and reflective feedback is shared at the team and back to the leading team.

At Wellston, the lead building team for the work also has representation from each grade level. Principal Cupp integrates practices into the building team meeting so teachers experience the practices themselves before taking them to the classroom:

We not only want to recognize and activate strengths in our students but in our staff as well. We are learning by doing and this paves the way to communicate 
and work better together. Knowing the strengths of our team supports our learning but it also helps with planning because we understand who to bring into an effort, where we are strong and what we might be missing.

In addition to building their own capacity in order to be reflective and effective coaches, the team is responsible for developing an ongoing calendar for implementation and creating supplemental materials as needed to support classroom implementation.

Grade level teams meet several times a week at Whitfield School. As part of those meetings they build practices for classroom implementation, where they are tested and refined. Director of Health and Wellness Ginny Fendell says in faculty meetings over the course of the year, they "experience the work they want to see in the classrooms, such as strengths spotting and practicing examples of under and overuse of strengths and discuss our experiences". Not only does this provide teachers with an opportunity for ongoing practice and reflection, according to Fendell, "teachers say it keeps us connected to the work and to one another".

\section{Conclusion}

After years of narrowing the scope of education to focus on a limited menu of academic priorities, it is encouraging to see the conversation expand to include more of our human capacity as worthy of concern and development. As researchers and practitioners in the field of positive education grow and scale the work in this emerging field, it will be critical to acknowledge the complexity of the endeavour, lest positive education be relegated to the accumulated repository of momentary education reforms. In fact, the challenges within education are excellent examples of what systems thinkers identify as wicked messes, meaning they are both technically challenging and socially challenging, and therefore necessitate a systems approach to change.

The critical elements of systems approach to change in implementing character strengths interventions are becoming clear as experts around the world seek to transform their schools. The experiences of these pioneers illuminate a path which is clear but not necessarily simple or easy. The outcomes evidenced with these systems interventions offer a return well worth the investment. Evolutionary evaluation indicates that activating character strengths to develop SEL competencies increases engagement, performance, and learning. Qualitative reports tell stories such as that of a Wellston student who was so deeply impacted by the work she made an impassioned presentation to the high school principal to expand the work beyond middle 
school, and the high school seniors whose character strengths were so important to them they wanted them included with their pictures in their school yearbook at Whitfield School.

The question that remains is whether we will have the patience and perseverance to act on what we know. In total, the wisdom emerging from the field suggests that success demands what Jim Collins (2001) says of organizations: "greatness is function of conscious choice and discipline" (p. 11).

\section{References}

Ackoff, R. (1986). Management in small doses. Hoboken, NJ: Wiley.

Au, W. C. C., \& Kennedy, K. J. (2018). A positive education program to promote wellbeing in schools: A case study from a Hong Kong school. Retrieved from https:// files.eric.ed.gov/fulltext/EJ1189599.pdf.

Berkowitz, M. W., \& Bier, M. C. (2007). What works in character education. Journal of Research in Character Education, 5(1), 29-48.

Berkowitz, M., Bier, M., \& McCauley, B. (2016). Effective features and practices that support character development. Retrieved from https://sites.nationalacademies.org/ cs/groups/dbassesite/documents/webpage/dbasse_173493.pdf.

Betts, F. (1992). How systems thinking applies to education. Educational Leadership, 50(3), 38-41. Retrieved from http://www.ascd.org/publications/educationalleadership/nov92/vol50/num03/How-Systems-Thinking-Applies-to-Education. aspx.

Block, P. (2003). The answer to how is yes: Acting on what matters. San Francisco, CA: Berrett-Koehler.

Bohlin, K., (n.d.). Virtue: An argument worth rehearsing. Retrieved from https:// www.questia.com/library/journal/1P3-3403566061/virtue-an-argument-worthrehearsing.

Bu, H., \& Duan, W. (2018). A single-session positive cognitive intervention on first-year students' mental health: Short-term effectiveness and the mediating role of strengths knowledge. Journal of American College Health. Advance online publication. http://dx.doi.org/10.1080/07448481.2018.1497639.

Calderhead, J. (1989). Reflective teaching and teacher education. Teaching and Teacher Education, 5(1), 43-51.

Calkins, A. (2015). It's time to trash the terms "non-cogs" and "soft skills". Retrieved from https://www.nextgenlearning.org/articles/its-time-to-trash-theterms-non-cogs-and-soft-skills.

Chase, C. S., Chin, D. B., Oppezzo, M. A., \& Schwartz, D. L. (2009). Teachable agents and the protégé effect: Increasing the effort towards learning. Journal of Science and Educational Technology, 18, 334-352. 
CIPD. (2017). Strengths-based performance conversations: an organizational field trial. Retrieved from https:/www.cipd.co.uk/knowledge/fundamentals/people/ performance/strengths-based-conversations.

Collins, J. (2001). Good to great. New York, NY: HarperCollins.

Connell, C., Martin, J., \& Moore, L. (2002). The Annenberg challenge: Lessons and reflections on public school reform. Retrieved from https:/www.issuelab.org/res ource/the-annenberg-challenge-lessons-and-reflections-on-public-school-reform. html.

Craft, M. (1984). Education for diversity. In M. Craft (Ed.), Education and cultural pluralism (pp. 5-26). London and Philadelphia: Falmer Press.

Darwish, J. (n.d.). Activating character strengths in the classroom. Retrieved from https://www.viacharacter.org/topics/articles/activating-character-strengthsin-the-classroom.

Darwish, J., (2001). Changes in the attitude, knowledge and behavior of beginning teachers engaged in a reflective mentor relationship (Doctoral Dissertation). University of Cincinnati.

Erickson, T. (2012). It's time to re-think the U.S. education system. Harvard Business Review. Retrieved from https://hbr.org/2012/08/todays-youth-challenge-usto-r.

Finkel, E. J., Slotter, E. B., Luchies, L. B., Walton, G. M., \& Gross, J. J. (2013). A brief intervention to promote conflict reappraisal preserves marital quality over time. Psychological Science, 24(8), 1595-1601. https://doi.org/10.1177/095679 7612474938.

Forest, J., Mageau, G. V. A., Crevier-Braud, L., Bergeron, L., Dubreuil, P., \& Lavigne, G. V. L. (2012). Harmonious passion as an explanation of the relation between signature strengths' use and well-being at work: Test of an intervention program. Human Relations, 65(9), 1233-1252.

Fullan, M. (1995). The limits and the potential of professional development. In T. Guskey \& M. Huberman (Eds.), Professional development in education: New paradigms and practices. New York: NY: Teachers College Press.

Gander, F., Proyer, R. T., Ruch, W., \& Wyss, T. (2013). Strength-based positive interventions: Further evidence for their potential in enhancing well-being. Journal of Happiness Studies, 14, 1241-1259.

Gillham, J., Adams-Deutsch, Z., Werner, J., Reivich, K., Coulter-Heindl, V., Linkins, M., et al. (2011). Character strengths predict subjective well-being during adolescence. Journal of Positive Psychology, 6(1), 31-44.

Grantmakers for Education. (2010). Innovation in education: redesigning the delivery system of education in America. Retrieved from edfunders.org.

Helliwell, J. (2019). World government summit. Retrieved from https://www.wor ldgovernmentsummit.org/events/annual-gathering/speaker-detail/636843582086 451762-john-helliwell.

Huffman, J. C., Millstein, R. A., Mastromauro, C. A., Moore, S. V., Celano, C. M., Bedoya, C. A., et al. (2016). A positive psychology intervention for patients with an acute coronary syndrome: Treatment development and proof-of-concept 
trial. Journal of Happiness Studies, 17(5), 1985-2006. https://doi.org/10.1007/ s10902-015-9681-1.

Josephson Institute: Center for Youth Ethics. (2013). TEAM: Teach, enforce, advocate, and model. Retrieved from https://charactercounts.org/resources/team.html.

Kim, D. (2008). Transformational dialogue for public education: 50 state strategy. Manuscript in preparation.

KIPP Foundation. (n.d.). Focus on character. Retrieved from https://www.kipp.org/ approach/character/.

Lavy, S. (2019). A review of character strengths interventions in twenty-first-century schools: Their importance and how they can be fostered. Applied Research in Quality of Life. https://doi.org/10.1007/s11482-018-9700-6.

Linkins, M., Niemiec, R. M., Gillham, J., \& Mayerson, D. (2015). Through the strengths lens: A framework for educating the heart. Journal of Positive Psychology, 10(1), 64-68. https://doi.org/10.1080/17439760.2014.888581.

Mayerson Academy. (n.d.). Amplifying student strengths. Cincinnati, OH: Mayerson Academy.

Mayerson Academy. (2015, 2016, 2017, 2018, 2019). Thriving learning communities $^{\mathrm{TM}}$ classroom curriculum guides: Grades K-12. Cincinnati, $\mathrm{OH}$ : Mayerson Academy.

Academy, Mayerson. (2018). Thriving Learning Communities ${ }^{\mathrm{TM}}$ evaluation report: $A$ summary of evaluation data from the Thriving Learning Communities program in 41 urban schools. Cincinnati, $\mathrm{OH}$ : Author.

McGrath, R. E. (2018). What is character education? Development of a prototype. Journal of Character Education, 14(2), 23-35.

McQuaid, M., \& Lawn, E. (2014). Your strengths blueprint: How to be engaged, energized, and happy at work. Albert Park, VIC: Michelle McQuaid.

Moen, R. (n.d.). Foundations and history of the PDSA cycle. Retrieved from https:// deming.org/uploads/paper/PDSA_History_Ron_Moen.pdf.

Niemiec, R. M. (2018). Character strengths interventions: A field-guide for practitioners. Boston: Hogrefe.

Oppenheimer, M. F., Fialkov, C., Ecker, B., \& Portnoy, S. (2014). Teaching to strengths: Character education for urban middle school students. Journal of Character Education, 10(2), 91-105.

Organisation for Economic Co-operation and Development. (n.d.). Social and emotional skills well-being, connectedness and success. Retrieved from http://www. oecd.org/education/school/UPDATED\%20Social\%20and\%20Emotional\%20S kills\%20-\%20Well-being,\%20connectedness\%20and\%20success.pdf\%20(web site).pdf.

Park, N., \& Peterson, C. (2006). Moral competence and character strengths among adolescents: The development and validation of the Values in Action Inventory of Strengths for Youth. Journal of Adolescence, 29, 891-905.

Payne, C. (2008). So much reform, so little change: The persistence of failure in urban schools. Cambridge, MA: Harvard Education Press. 
Peterson, C., \& Seligman, M. E. P. (2004). Character strengths and virtues: A handbook and classification. New York, NY: Oxford University Press/Washington, DC: American Psychological Association.

Positive Psychology Research Center. (n.d.). Strengths gym. Retrieved from http:// www.pprc.gg/products/.

Proctor, C., Tsukayama, E., Wood, A., M., Maltby, J., Fox Eades, J., \& Linley, P. A. (2011). Strengths gym: The impact of a character strengths-based intervention on the life satisfaction and well-being of adolescents. Journal of Positive Psychology, 6(5), 377-388.

Quinlan, D. M., Swain, N., Cameron, C., \& Vella-Brodrick, D. A. (2014). How 'other people matter' in a classroom-based strengths intervention: Exploring interpersonal strategies and classroom outcomes. Journal of Positive Psychology. https://doi.org/10.1080/17439760.2014.920407.

Quinlan, D., Vella-Brodrick, D. A., Gray, A., \& Swain, N. (2019). Teachers matter: Student outcomes following a strengths intervention are mediated by teacher strengths spotting. Journal of Happiness Studies, 20, 2507-2523. https://doi.org/ 10.1007/s10902-018-0051-7.

Rospert, C. (2017). Character strengths: Optimizing relationship building for community change. Retrieved from http://strongcincinnati.org/character-strengths-opt imizing-relationship-building-for-community-change/.

Schoen, D. (1984). The reflective practitioner: How professionals think in action. New York, NY: Basic Books.

Schutte, N. S., \& Malouff, J. M. (2018). The impact of signature character strengths interventions: A meta-analysis. Journal of Happiness Studies. Advance online publication. http://dx.doi.org/10.1007/s10902-018-9990-2.

Schweiger, S., Stouten, H., \& Bleijenbergh, I. (2018). A system dynamics model of resistance to organizational change: The role of participatory strategies. Retrieved from https://onlinelibrary.wiley.com/doi/pdf/10.1002/sres.2509.

Seligman, M. E. P. (1999). The president's address. American Psychologist, 54, 559562.

Seligman, M. E. P. (2011). Flourish. New York, NY: Free Press.

Seligman, M. E. P., Ernst, R. M., Gillham, J., Reivich, K., \& Linkins, M. (2009). Positive education: Positive psychology and classroom interventions. Oxford Review of Education, 35(3), 293-311.

Senge, P. (1990). The fifth discipline: The art and practice of the learning organization. New York, NY: Random House.

Shoshani, A. (2019). Young children's character strengths and emotional well-being: Development of the character strengths inventory for early childhood (CSI-EC). Journal of Positive Psychology, 14(1), 86-102.

Shoshani, A., \& Ilanit Aviv, I. (2012). The pillars of strength for first-grade adjustment-Parental and children's character strengths and the transition to elementary school. Journal of Positive Psychology, 7(4), 315-326. 
Shoshani, A., \& Shwartz, L. (2018). From character strengths to children's wellbeing: Development and validation of the character strengths inventory for elementary school children. Frontiers in Psychology, 9, 2123. http://dx.doi.org/ 10.3389/fpsyg.2018.02123.

Shoshani, A., \& Slone, M. (2013). Middle school transition from the strengths perspective: Young adolescents' character strengths, subjective well-being, and school adjustment. Journal of Happiness Studies, 14(4), 1163-1181. https://doi. org/10.1007/s10902-012-9374-y.

Sprinthall, A., Reiman, A., \& Thies-Sprinthall, L. (1996). Teacher professional development. In J. Sikula (Ed.), Handbook of teacher education (2nd ed.). New York: Simon and Schuster McMillan.

Stoll, L., Bolam, R., McMahon, A., Wallace, M., \& Thomas, S. (2006). Professional learning communities: A review of the literature. Retrieved from https://link.spr inger.com/article/10.1007/s10833-006-0001-8.

Understood Team. (n.d.). The difference between the Every Student Succeeds Act and No Child Left Behind. Retrieved from https://www.understood.org/en/school-lea rning/your-childs-rights/basics-about-childs-rights/the-difference-between-theevery-student-succeeds-act-and-no-child-left-behind.

VIA Institute. (2016). VIA assessments. Available at: https://www.viacharacter.org/res earchers/assessments.

VIA Institute (2019). What the research says about character strengths. Available at: https://www.viacharacter.org/research/findings.

Walton, G. M. (2014). The new science of wise psychological interventions. Current Directions in Psychological Science, 23, 73-82. https://doi.org/10.1177/096372 1413512856.

Weber, M., Wagner, L., \& Ruch, W. (2016). Positive feelings at school: On the relationships between students' character strengths, school-related affect, and school functioning. Journal of Happiness Studies, 17, 341-355. https://doi.org/10.1007/ s10902-014-9597-1.

Wheatley, M. (Spring, 2001). Innovation means relying on everyone's creativity. Retrieved from https://www.margaretwheatley.com/articles/innovationmeans. html.

White, M. A., \& Waters, L. E. (2015a). A case study of 'The Good School:' Examples of use of Peterson's strengths-based approach with students. Journal of Positive Psychology, 10(1), 69-76. https://doi.org/10.1080/17439760.2014.920408.

White, M., \& Waters, L. E. (2015b). In M. White \& A. Murray (Eds.), Evidencebased approaches in positive education: Implementing a strategic framework for wellbeing in schools (pp. 111-134). Dordrecht, Heidelberg, New York, and London: Springer.

World Economic Forum. (2016). Skills stability. Retrieved from http://reports.wef orum.org/future-of-jobs-2016/skills-stability.

World Government Summit. (2019). Annual gathering speaker detail. Retrieved from https://www.worldgovernmentsummit.org/events/annual-gathering/spe aker-detail/636843582086451762-john-helliwell. 
Yeager, D. S., Johnson, R., Spitzer, B. J., Trzesniewski, K. H., Powers, J., \& Dweck, C. S. (2014). The far-reaching effects of believing people can change: Implicit theories of personality shape stress, health, and achievement during adolescence. Journal of Personality and Social Psychology, 106 (6), 867-884. https://doi.org/10. 1037/a0036335.

Yeager, D., \& Walton, G. (2011). Social-psychological interventions in education: They're not magic. Review of Educational Research, 81(2), 267-301. Retrieved from https://pdfs.semanticscholar.org/94c8/d911a73e39511fca0d9cedcde5b795 95d5f6.pdf.

Open Access This chapter is licensed under the terms of the Creative Commons Attribution 4.0 International License (http://creativecommons.org/licenses/by/4.0/), which permits use, sharing, adaptation, distribution and reproduction in any medium or format, as long as you give appropriate credit to the original author(s) and the source, provide a link to the Creative Commons license and indicate if changes were made.

The images or other third party material in this chapter are included in the chapter's Creative Commons license, unless indicated otherwise in a credit line to the material. If material is not included in the chapter's Creative Commons license and your intended use is not permitted by statutory regulation or exceeds the permitted use, you will need to obtain permission directly from the copyright holder. 